\title{
Iran's Constitutional Revolution and Religious Reactions to It
}

\author{
Seyed Milad Kashefi Pour Dezfuli ${ }^{1}$ \\ ${ }^{1}$ Department of International Relations, Law and Political Science, University of Tehran, Tehran, Iran \\ Correspondence: Seyed Milad Kashefi Pour Dezfuli, Department of International Relations, Law and Political \\ Science, University of Tehran, Tehran, Iran.
}

Received: May 26, 2016

doi:10.5539/ass.v12n11p11
Accepted: June 28, $2016 \quad$ Online Published: October 14, 2016

URL: http://dx.doi.org/10.5539/ass.v12n11p11

\begin{abstract}
Half a century of intellectual debates and efforts to political reforms following Iran's defeat against Czarist Russian Empire at two series of wars at 1810s and 1820s, led to the Constitutional Revolution of 1906 which put an end to a thousand-year-old despotic monarchical order. However, the success of the revolution and the establishment of Iran's first legislative Assembly (Majlis) didn't ended controversy between advocates of traditional order and widespread front of supporters of modernism which was begun decades earlier. New ruling system with its modern institutions could not satisfy opponents of modernism and supporters of traditional monarchy. From decades before Constitutional revolution, introduction of modern concepts had created rifts in the content of traditional ones but so far as these modern concepts hadn't turned to parts of socio-political realities of the country and hadn't unsettled traditional order, controversy between advocates and opponents of modernism couldn't transform into an all-out and pervasive conflict. It was then that traditionalists realized the depth of dangers modern concepts can present against traditional political order.
\end{abstract}

Keywords: Iran's constitutional revolution, legitimacy, modernism, Shia political thought, conceptual history theory

\section{Introduction}

During Qajar dynasty's history, there were numerous campaigns for modernizing the socio-political order and institutions of the country, but despotism of the Shahs was an obstacle for every meaningful achievement. Deterioration of the affairs of state during the reign of Nasir-al-Din Shah, sometimes was reaching to points that even the Shah himself had to contemplate reforms and yet no solution was found to reconciled modern reforms with tyranny of the Shah. More than anything, political reforms required securing of fundamental freedoms; Shah and a large part of the ruling clique were more accustomed to the long tradition of despotism than to be able to acquiesce to the requirements of a modern political order. Constitutional movement was a response to the dilemma between the continuation of tyranny and the quest for freedom and modernization, however, following the overthrow of the despotic order and its institutions, the country was stuck into such a massive disorder and disruption in some provinces resulted from domination of anarchists and hoodlums that even a great many of the staunchest sympathizers of the revolution started to worry about the legitimacy of the new order and the people consent and some of them even began to warn of the failure of the revolution.

Furthermore a religious and juridical debate began among Shia scholars and clerics regarding the legitimacy of the new constitutional government. Underestimated in comparison with the efforts of secular intellectuals to introduce modern political ideas such as freedom, constitutionalism and democracy; these debates had wide-ranging yet neglected consequences for the evolution of modern Shia political thought and later developments in Iran's modern history, including Islamic Revolution of 1979. Adaptability of modern political ideals and the requirements of a constitutional governing system with Islamic principles and the laws of Shia Sharia (jurisprudence) was the most heated and controversial issue in the debates between two groups of Ulema (religious scholars and jurists). One group stood against what was a heresy in their views, challenging the idea that certain principles of the new Constitution such as the concept of citizenship, equality among all citizens regardless of their faith and gender, freedom of thought, speech and press and so on could be reconciled with incontrovertible Islamic doctrines. Furthermore, they ventured to criticize principles of modern Western political thought and labeled them as ideas and beliefs inherently in conflict with Islamic norms and rules, while another group rose to defend constitutionalism and to counter arguments brought up by the first group. 
In what follows I will try to give an account of these debates focusing solely, albeit, on two prominent figures in the two camps. Sheik Fazl-Allah Nouri among opponents and Allameh Mohammad Hussein Naiini among advocates of constitutional government. Most of the sources, documents and treatises related to this period of the history of Iran are kept unpublished in public or private collections and no one really has much access to them, while most literature produced in the past hundred years about Constitutional Revolution has been written by those who have shown no inclination in compiling a conceptual history for Iran's transformations in the new era of her history. Among those few who have indeed paid any attention to intellectual spheres of Iran's transformations in this period the main concerns were secular intellectuals or the followers of the Western ideologies of the twentieth century. For example, Freidon Adamiat's researches on the intellectual aspects of Constitutional movement are among few scholarly works which nonetheless, are confined almost totally on secular intellectuals and have paid no attention to intellectual disputes between religious figures at the time (Adamiat, 1956). Some of the treatises written by clerics associated with opponents or advocates of constitutionalism have been published by Homa Nateq in her "Economic and Socio-Political Thoughts in Unpublished Works of Qajar Period". But again one can see that even in these rare instances of considering intellectual transformations associated with Constitutional movement, there are still shortages in terms of looking at the origins of a spectacular phenomenon like the emergence of intellectuals in the sphere of learning and knowledge in Iran.

It should be understood that writing a conceptual history of the intellectual transformations of Iran especially those in the realm of political thought would be of utmost significance in unfolding the logic of historical developments of Iran in the new age and also grasping an idea of what they may bear in the future. Sadly Iran's historiography both official and non-official has been plagued by political considerations and ideological strifes. On the one hand official historiography after the Islamic Revolution of 1979 has tried to purify Sheik Fazl-Allah as a sage who foresaw all the difficulties an unbound-to-Sharia constitutionalism would encounter and on the other hand secular historians have tended to underestimate the importance of the religious debates revolving around religious legitimacy of constitutionalism between Sheik Fazl-Allah and his opponents. An example of this tendency could be found in "Iranian Mashrooteh: backgrounds of the theory of Velayat-e-Faqih (sovereignty of Shia jurist)" written by Masha-Allah Ajodani, Iranian expatriate intellectual living in London. Fortunately in recent years Dr. Seyed Javad Tabatabai's works especially "The Theory of the Rule of Law in Iran" has shed some light on the significance of those debates in later developments of modern Shia political thought. Also, considerable literature has been produced among Iranian academics living abroad on the subject of Iranian Muslims reactions to modernity which in study dedicated to Constitutional movement could be valuable sources. Works such as Mangol Bayat's "Iran's First Revolution: Shi' ism and Constitutional Revolution of 1905-1906", Farhang Rajaee's "Islamism and Modernism: Changing Discourse in Iran" and Said amir Arjomand's "Constitutional Politics in the Middle East: With Special Reference to Turkey, Iraq, Iran and Afghanistan" are among them.

My methodology in this project will be based on a qualitative approach of data gathering and analysis. All relevant documents including primary sources such as the constitution of 1906 and the publications of Shia writers in the period of Constitutional Revolution and secondary sources, namely those which has been written by historians and scholars researching on modern Shia political thought will be investigated and analyzed with a critical view in order to find out the evolution of basic concepts and ideas pertaining to the debate on the religious legitimacy of the Iran's Constitutional government. A framework based on conceptual history theory which assumes that concepts and cultural values and practices should be understood in their particular contexts and not as unchanging ideologies and processes would be of great significance in my research as this research method could be used to suggest that it was evolutions in traditional Shia concepts which made possible the development of modern Shia political thought.

\section{Political Context}

Constitutional movement won with issuance of Mozaffar-al-Din Shah's command, but it wasn't a complete and reliable victory. Shah was bedfast at the time and he died a few days later. His successor, Mohammad Ali Shah who was grown up with despotic tempers, could not get along with new order, he tried to extort a letter from his father's physician that he had lost his mind at the time of issuing the Constitutional (Mashruteh) command so that the new king be able to declare it void. More temperate courtiers compelled Shah to stop vain efforts and to declare his adherence to the principles of constitutionalism and his support for the new Constitution. Mohammad Ali Shah gave the position of chancellery to Amin-al-Sultan who had the same position at the reign of both his grandfather and father; Amin-al-Sultan was famous for corruption and the public hated him. His repute and background was without even a single bright spot, however, he had spent four years in trotting the globe 
including long stays in Japan and United States; these experiences made him realize the necessity of reforms in Iran and to learn by the examples of countries he had visited. His first condition for accepting the position of chancellery was that, Shah can't expect him to contend with parliament and he should remain loyal to constitution as well (Adamiat, 1956, pp. 53-54). He had said that "constitutionalism is a natural demand and no one can stop its progress and no one should resist it" (Adamiat, 1956, p. 54). It was for this very change in Amin-al-Sultan views that majority of parliament welcomed his return to the country and his appointment to the chancellery despite his bleak background and gave a vote of confidence to his cabinet.

The most exigent problem in the path of reforms was to establish security and the rule of law. Political openness after revolution occasioned chaos in some provinces and in some cases the instigator behind this chaos was Shah himself who was trying to disrupt the foundations of the new order. For instance, in Tabriz a conflict broke out between revolutionaries and the Qaradaq tribe under the command of Biok Khan and 200 people were killed in the fighting. Because Sardar Nosrat, Biok Khan's father was close to Shah, parliament blamed Shah for the incident and Biok Khan's summon to Tehran by Shah to silence parliament was not enough to placate them. In such a situation Amin-al-Sultan intervened and arrested Sardar Nosrat, as parliament had requested. This was the first sign of disagreement between Shah and his chancellor but small numbers of extremist members of parliament would not shy away from any sabotage in the administration of affairs by the cabinet, regardless of all the differences in the manners and views between Shah and the chancellor, while the more moderate members were increasingly acknowledging Amin-al-Sultan loyalty to principles of constitutionalism and were recognizing the fact that it is Shah and his courtiers that are equally conspiring against both parliament and cabinet.

While the cleavages between court-cabinet and cabinet-parliament was increasing due to seductions of Shah and radical members of parliament, Amin-al-Sultan threatened that he would resign and leave Iran. Shah succumbed to the will of his chancellor in the last minutes and sent a letter to Majlis, declaring that he will refrain from any action against parliament and constitutionalism. Chancellor took the letter to Majlis and read it there; he expressed his hopes that things will ameliorate henceforth. He was assassinated in his way out of parliament and according to the investigations Heidar Khan, a member of secret committee of an anarchist-socialist party was the instigator behind the assassination and commissioned a group to execute it.

Like any other democratic change, one of the consequences of Iran's constitutional movement was the establishment of the institutions of the new order and the consolidation of liberties; an order stemmed from sovereignty of people could not be possible except with participation and involvement of them in the administration of affairs, nevertheless, people's participation in a country like Iran which had got used to political despotism for centuries, could be like a two edged sword. As long as wise politicians had the movement in their control, constitutional revolution was a reform-oriented and peaceful movement but when extremist groups and demagogue leaders started to enter the field of politics, constitutional regime turned into a battlefield between reformists and advocates of radical solutions. Political participation of the masses materialized through socio-political associations and while the first parliament was at the beginning of its work, the interventions of these associations members was among the most important barriers to progress and it even was disrupting public order at times. Indeed, foolish, not to say self-interested revolutionaries of these associations were turn into barriers preventing establishment of the rule of law and its institutions. Against anarchist radicals like Heidar Khan, more temperate advocates of constitutionalism were trying, as far as possible to solve the problems of the country by enacting laws and providing the conditions to enforce them. Among these constitutionalists there were those who knew from the beginning that if things don't proceed rationally, there is this fear that tyranny of Shah will be replaced by tyranny of hoodlums. One of these people was Mirza Fazl Ali Tabrizi, a ranking religious leader from Azerbaijan and a member of the first parliament from Tabriz who put forward short but interesting references to the new spirit of tyranny in his writings.

In Mirza Fazl Ali Tabrizi's notes there are significant references to some of discussions among constitutionalists at this time. With the fruition of revolution, significant efforts began to establish institutions of the rule of law but until first parliament started its work it wasn't clear what conflicts could emerge between the new order and the beliefs of advocates of traditional order. Equality of all citizens was among the primal principles of the rule of law, no such ruling system could exists without legal equality, however, religious leaders even those who had contributed in the success of revolution couldn't or didn't want to accede to this requirement of the rule of law. According to the laws of Sharia - Islamic canon - believers of other faiths were required to pay ransom but in a constitutional system, tax - which was levied on all citizens equally - was to be replaced that ransom in the case of non-Muslims and this change and its implications which signified a departure from that fundamental distinction between two groups of citizens in religious laws wasn't compatible with the text of Sharia and thus, the views of traditional-minded believers. Religious scholars like Sheik Fazl-Allah Nouri who expected nothing 
of constitutional government but a complete enforcement of the laws of Sharia, soon realized the basic requirements of the rule of law and began to oppose it. With their different understanding of the basics of Islamic laws, however, advocates of constitutional order believed the equality of citizens to be compatible with the spirit of religion and treated the rule of law in constitutionalism as the exact purpose of the enforcement of the laws of Sharia. This debate turned into prolonged and vociferous controversies during the first parliament's negotiations and then ended in a compromise. In opposition to Sheik Fazl-Allah and other like-minded clerics, Mirza Fazl Ali, one of the top-ranking religious scholars in parliament was among advocates of equality between citizens. He maintained that rule of law and citizenship system is necessary for the establishment of a national government, a rule of law without legal equality of all citizens would be nothing but one group's domination over the others (Mirza Saleh, 1993, pp. 51-52). Mirza Fazl Ali believed that establishment of the rule of law, economic development and building a healthy society free of tensions would only be possible in a situation that all peoples in that society are partners in the administration of affairs as a single nation and in that regard so-called religious barriers are only excuses to keep the interests and incomes of Nouri and the other tyrants intact (Mirza Saleh, 1993, p. 52).

Political and economic developments of the Qajar period led to the success of constitutional movement and an important effort began to create a new order which was unprecedented in Iran's history. Under Qajar rule, there were efforts to modernize socio-political institutions but despotism close the doors to every meaningful transformation. In Nasir-al-Din Shah's reign, the deterioration of the state affairs got so tense at times that even Shah himself would think of reforms but it wasn't possible to find reconciliation between reforms and despotism. More than anything, reforms needed adherence to basic freedoms but Shah and a large part of ruling elites, having got used to a long-lasted tradition of political despotism, didn't want to accede to requirements of a free order. Constitutional movement won in the deadlock between continuation of despotism and the quest for freedom and modernization, but with the elimination of despotic order and its institutions, serious disorders emerged in some of provinces. With their interventions, anarchist elements created an environment in which court-supported hoodlums took control of the situation (Mirza Saleh, 1993, p. 60) and radical advocates of constitutionalism who had contributed in furthering disorders and disruptions unintentionally helped them. Thus in people's minds, the legitimacy of constitutional government was damaged and many took the failure of reforms as granted. It was in such conditions that reformist and especially those among them who had religious orientations noticed implications of losing legitimacy and tried to find an appropriate middle way between despotism and anarchy.

\section{Religious Opponents of Constitutionalism: The Views of Sheik Fazl-Allah Nouri}

The most outspoken opponent of constitutionalism among Shia clerics was Sheik Fazl-Allah Nouri and his views on illegitimacy of constitutional order and its conflict with principles of Islam has been propagated through a number of essays and sermons. One of these essays is in fact a bill on explanation of Sheik's opinions; it says that constitutionalism was a word came to Iran from Europe and its content was that monarchy is the origin of all corruptions and injustices. With continuation of monarchy, distress in people's lives and disruption in state affairs would reach to a degree that it may rob the country of its independence. Those who seek constitutionalism claim that only cure for this fatal illness is to transform arbitrary monarchy into a governing system in which there is "arrangements" for state duties and bureaucratic services and make Shah and his officials acts subject to that arrangements and let no one to breach them. Arrangements should be determined by consultations with wise and honest people among the subjects of state (Zargary, 1998, p. 170).

When great Shia clerics were informed of this matter, Sheik Fazl-Allah wrote, they met each other and reached to a consensus that state's wreck is mostly resulted from lawlessness and they confirmed that a national consultative assembly should be constituted. But with the opening of the assembly, disorder appeared and things happened that no one expected them and it caused panic for clerics and lay believers alike. Parliament was put into the hands of a group of careless and unfaithful people; newspapers began to vilify clerics of Islam and to taunt laws of Sharia, they claimed that parliament should intervene and adapt the laws which have been enacted 1300 years ago to conditions and requirements of the time, for instance freedom of the sale of alcohol and brothels shall be recognized, schools for girls and modern factories shall be opened and modern roads, streets and railways shall be built (Turcoman, 1983, pp. 260-261).

In Sheik's view prevalence of religious taboos and unfaithfulness in Tehran is resulted from the spreading of the word "freedom"; freedom of opinion is the origin of all social corruptions and harms, Majlis is twin of all evils and these things altogether have subjected the country to chaos and tumult. The origins of all problems are distortions occurred in the nature of parliament, it was meant to be an Islamic assembly not a national one, European codes weren't meant to be the basis of legislation, parliament was supposed to serve and assist the 
court and to protect the rights of Shia believers but it has fallen into the hands of some ungodly and libertine people who run it like a European parliament (Turcoman, 1983, p. 262). Sheik went on to claim that his declaration addressing Shah in which Majlis was introduced as a thing in conflict with principles of Islam was written in opposition to the same distortions occurred in the nature of parliament and claimed that in its current shape, parliament is not reconcilable with Islam (Ibid: 271).

In addition to his criticisms of revolutionary institutions, Nouri paid attention to concepts of constitutionalism. Revolutionaries deceived people with two concepts of justice and consultation, he asked people to wage an all-out war against modern concepts including freedom, otherwise soon there will be nothing left of Islam except a name. In Nouri's allusions to hasty process of changes and chaos after constitutional revolution, one could witness signs of genuine concerns about replacement of individual tyranny by a majority one which was also noticed by some moderate constitutionalists, however, it doesn't seem that Nouri had a realistic understanding of these changes and his insistence on his opinions until his execution signifies the same unawareness of the nature of modern times and also a democratic revolution which had begun in Iran's intellectual and political spheres from decades ago. Relying on his wrong estimates in a letter to Moshir-al-saltaneh, Mohammad Ali Shah's chancellor at the aftermath of Majlis's shot up in June 1908, Sheik asked the chancellor to show Shah that the flag of Islam is in his hands now and if that drops, country will fall into chaos and there will be bloodbath (Ibid: 254). Nouri saw the rise of constitutionalists in Tabriz (in reaction to Majlis's shot up and "The Lesser Tyranny" (Note 1) period) as a transient and temporal disturbance and was sure that if shah stands a few days more, rebels will disperse (Ibid: 257). This is enough to show that he had no clear notion of the unequal balance between the forces of a tyrant Shah and those who were fighting for freedom.

Along these bills and letters, two other short but significant essays have been written by Sheik Fazl-Allah in which his opinions on the unlawfulness of constitutional order and his verdicts on the question has been recorded. The essay "Unlawfulness of Constitutional Order" was written in response to a question on why Sheik supported the revolution at the beginning and then changed sides to oppose it? Nouri said that after revolution succeeded, some began to speak of fictitious things like election of representatives (Vakil-e-Majlis in Persian), majority vote and enacting laws; these were concepts incompatible with juridical opinions of Sheik. He maintained that representation (Vekalat in Persian which also means attorney) is a matter pertaining to private law and its extension to public matters is not allowable, if representation is given for secular matters no religious arrangement will be needed but if it is intended for public matters then it will be intervention in matters related to political authority which rests with Shia clerics at the age of the absence of the Hidden Imam (Note 2) and it is not for people to give to their representatives. Since Islam is the law of Muslims and they will need no other law beside that, enacting laws by majority votes is not allowable in Islam. (Ibid: 121) Sheik claimed that his disagreements with constitutionalists began by ratification of constitution; he wanted a constitutional order compatible with Sharia while revolutionaries were not ready to accede and they didn't saw constitutional order as a thing needed to be in conformity with Islamic and divine laws (Ibid, pp. 153-154).

Sheik's other objection on the question of legislation in constitutional government is about referring to public votes and electing representatives from all guilds and classes of people. He believed that public opinions and votes in legal matters even those spheres unregulated by Sharia would have no validity. Furthermore the main element of any law is its sanction while in matters unregulated in Sharia; the rule is that there is no obligation, so legislation by votes of majority in those matters will be innovation in religion as well (Ibid: 154). Nouri's objections to legislation in a constitutional order and the validity of the votes of people's representatives are stemmed from the basics of his canonical-political thought. He held that two spheres of prophecy and monarchy was integrated in the person of the Prophet of Islam and these authorities extended to his successors - although some of them were not his rightful successors - later occurrences caused a break between these two spheres and following this development, politics in Islam was based on a distinction between sacred and temporal, between the power to enforce the Laws of Islamic canons and the secular power of monarchy. Indeed monarchy is the executive power to enforce the laws of Sharia and justice will be served by implementing Sharia and its punishments which is among the duties of government (Ibid: 158) Relying on these basics, Sheik alluded to some of the conflicts between articles of constitution and principles of Islam. One of the most controversial articles of the constitution was legal equality of all citizens of state which was mentioned, albeit with some uncertainties in article eight of the amendment of the constitution: "The inhabitants of the state of Iran will be equal before the state laws." Nouri held the equality as a rule incongruent with Islam, not only he mentioned discriminations Between Muslims and non-Muslims which was acknowledged by other clerics as well but beyond that and with numerous examples he cited to differences between Muslims and subjects of the Sharia themselves regarding their rights and duties before the law and added that with all these differences the principle 
of equality before the law is contrary to Sharia and the faith. Even constraining equality to state laws - and not Sharia laws - will not solve the problem because if the state laws are going to be compatible with that of Sharia then the principle of equality shouldn't be there and if it is decided that the principle of equality should remain in the constitution then it is not conforming with the laws of Sharia (Ibid: 163-164).

One of the other problematic Principles of constitution in Sheik's view was freedom of press. Article 18 of the amendment of the constitution decreed that all public prints and publications except those of subversive books and publications harmful for faith are free and censorship is forbidden. Nouri claimed that this principle would render lawful many things unlawful in Sharia, however, his contentions in this regard was more a reaction to some behaviors he was witnessing in contemporary presses and not a theoretical challenge to the philosophy of freedom of press; for instance, he argued that defamation is illegal under the laws of Sharia while freedom of press will make it legal. Obviously Sheik's claims on the question of defamation was not correct, publication of untrue articles was regarded as a crime in legislated laws, however, punishment the legislator had assigned for it was among financial punishments which wasn't canonically recognized in Sheik's view. Worse than that, Sheik believed that such punishments instead of recognized ones in Sharia had no intention but to destroy the foundations of faith and Sharia (Ibid: 178).

The argument on the illegality of punishments in parliament's legislations is a prelude for a third and a much wider objection: the laws of criminal procedure. The most important aim of the Constitutional revolution was to found an assembly to enact necessary laws in order to establish rule of law, parliament's efforts to transform laws of Sharia into modern civil code didn't faced with serious resistance, however, adapting canonical criminal procedures, crimes and punishments to the philosophy of modern criminal law could not easily attract compliance of traditionalist antagonists. Article 12 of the amendment of the constitution had forbidden issuance of any sentence of punishment and its enforcement except by due processes of law. In opposition to this, Nouri was claiming that enforcement of laws and implementation of punishments in Islam does not require enacting laws and at the age of absence of the Hidden Imam, it is the duty of Shia clerics to judge disputes and to enforce punishments according to the rules of Sharia (Ibid: 182-183).

In addition to these specific and slight objections, Nouri paid his attention to more fundamental and significant objections as well. He maintained that there are more than twenty subjects explicitly in conflict with principles of Islam in the constitution (Ibid: 186); one of the most significant of them is the theory of the separation of powers which is considered as one of the most fundamental theories of the rule of law. Also, in Nouri's view, Legislature is a sheer aberration since Islam doesn't need legislation and so the establishment of an assembly for legislation modeled on that which exists in European modern states and enacting new laws is without any doubt, innovation in religion. In reaction to those like Talibof Tabrizi which had said in the "Book of Ahmad" (Note 3) that: "if we want to have modern laws, we should add at least thirty thousand new articles to the existing ones in Sharia" (Ibid: 187). Nouri warned that this proves the conspiracies of constitutionalists to abolish Sharia and declared that in those matters happening after the giving of Sharia by God to Prophet, one should refer to vicars of the hidden Imam (Shia Clerics) so that they find a solution by deduction from Quran and the ways of Prophet and Imams and not to enact or forge new laws.

In the essay "Reminder to negligent and guidance to ignorant", Sheik surveys the innovativeness of constitutionalism on a wider perspective of the philosophy of prophecy. Every society needs laws so that order and coherence survives on that society and since divine laws are the best of laws and the most perfect divine laws is that imparted to men by the prophet of Islam which contains politics as well as worship; the nation of Islam does not need to enact new laws. Confession to the prophecy of the prophet Mohammad is among the principles of Islam, no one can be regarded Muslim without such a confession. Afterwards and with a reference to the misgiving "requirements of times changes or supplements some divine laws", Nouri says that the laws of Islam is the sealing of divine laws, it means what is required by the good of men until the end of the world, has been expressed by the prophet of Islam; thus establishment of the constitutional assembly as a legislature is in conflict with the sealing of prophecy and therefore contrary to Islam (Ibid: 192) In following his objections to the constitution which was mentioned in discussion of Sheik's earlier essays and writings, he wrote in his new essay that there are mutable articles in the constitution and the constraints that has been anticipated that constitutional laws shall not be contrary to those of Sharia is a mere subreption since if the laws are mutable then those laws which are in conformity with the laws of Sharia can be replaced by those which are not (Ibid: 195).

Sheik Fazl-Allah believed that with the demise of the Prophet of Islam and the end of the age of four Caliphs after him, the unity of Islamic land lost and the political authority transferred to Sultans, while like many Shia clerics in history he held that monarchy is a kind of unjust and thus illegitimate government but this proposition didn't hindered him from rising in its defense against the innovations of constitutionalism. He objected to 
constitutionalists that their actions has caused seduction and weakening of the Sultan of Islam (Shah of Iran). He said that constitutionalists claim that establishment of a constitutional government will strengthen Islam is a lie, if their intention is to strengthen Islam then why they are weakening the Sultan of Islam? (Ibid: 202) Here in his essay and with an allusion to three characteristics which exist in Iran and do not exist in other countries with constitutional governments, Sheik turns to a pragmatic discussion of barriers of the establishment of a constitutional government in Iran. The first characteristic is that Iran is a country with many faiths and since there are enmities between followers of these faiths if a constitutional government establishes in Iran, her survival as the only Shia country in the world will be endangered. Second characteristic is related to the low number of her armed forces and the third is about the multiplicity of tribes and ethnicities living in her borders, while other countries with constitutional governments have regular and strong armed forces and they have suppressed their tribes. Based on these arguments he concluded that with the establishment of a constitutional government, tribal rebellions will inundate the country and no one can be sure of his life and properties and even there is a fear that there will be nothing left of Shia faith other than a name (Ibid: 205).

At the end of his essay and relying on these opinions, Sheik advised constitutionalists that if they want to establish a constitutional government, first they should seek to strengthen the Sultan so that he can conscript a strong army and deploy it across the country so that establishment of a constitutional government does not lead to anarchy (Ibid: 208-209). These last sentences of his essay is a sign of distraught and confusion in his opinions since despite believing in the incongruity between constitutional government and principles of Islam, he ventured thus to give his advises on how to establish such a government in Iran and he even didn't pay attention to the fact that his essay has been turned into a defense bill for despotic monarchy. Nonetheless, it was with his objections and the replies given to him by clerics advocating constitutional revolution that a major era began in the history of development of the Shia political thought.

\section{Religious Advocates of Constitutionalism: The Political Thought of Allameh Naiini}

With the success of the constitutionalists uprising against "the lesser tyranny" in Tabriz and the execution of Sheik Fazl-Allah Nouri, the fractures in the traditional order had deepened to such an extent that made the possibility of reconciliation between two differing understandings of that tradition, obsolete. Surveying documents and sources proves that, despite some instances of fallacies and distortions, the writings and statements of Sheik Fazl-Allah had an otherwise acceptable degree of coherence and he never reneged on his beliefs which were based on the text of Sharia. In contemporary reports one could see that sometimes, Sheik's arguments won over that of his opponents in debates and they had to evade from replying to his disputations (Zargary, 1998, p. 526). One could find in these reports that Sheik was defending a logic that constitutionalist leaders such as Sheik Mohammad Tabatabaii had not the theoretical ability to encounter with it. The debate was about the theoretical foundations of Nouri's opinions and one could answer his disputations that have made a revision in the theoretical foundations of religious learning while among constitutionalist opponents of Nouri there were few people who had risked doing it.

Although after the victory of the constitutional revolution and in encounter with a far-reaching alliance consisted of wide spectrum of social groups and classes in support of the rule of law, Sheik and his like-minded had to join to Shah and his supporters, but Sheik's views on monarchy was more complex than that which his opponents with the charge of being reactionary were attributing to him. Sheik was ready to comply with constitutionalism as long as it was interpreted as restriction of Shah's powers in the confines of Sharia, however, when some leading constitutionalists began to declare that in a constitutional government there will be restrictions for Sharia itself, unknown spheres of constitutional philosophy was unfolded for Nouri that was not in conformity with his beliefs in the appearances of the rule of Sharia. For Sheik the principle was to defend the authority of Sharia not that of Shah and he was explicitly articulating that Shah's authority at the age of absence should be strengthened merely as an instrument to enforce the laws of Sharia.

There were famous clergymen present at the wide-spread alliance of constitutionalist groups which embarked on defending its legitimacy by publication of their essays however, among all of them it was only Mirza Mohammad Hussein Naiini a junior jurist close to some of grand Ayatollahs of Najaf that offered a theoretical defense of the entirety of constitutionalism's principles and consolidated the legitimacy of the rule of law by compiling his essay by the title of "A Warning to the faith community and Purification of the nation". In addition to defending constitutional government, the essay was a very important one in the confines of the Shia theory of unjust government and in fact it should be seen as the first orderly essay in Shia political thought since the writer has discussed all the principles and origins of Shia political thought and benefiting from theoretical basics of Shia jurisprudence, in addition to revealing the corrupt aspects of Sheik Fazl-Allah opinions he has offered a scheme of a Shia theory of government. 
At the beginning of his essay, Naiini wrote that constitutional movement started when the decadence of Islamic world had been unprecedentedly intensified. With awareness of the requirements of their faith and conscious of their God-given liberties, Muslims realized their equality with their cruel rulers and rose to reclaim their rights. Despotic monarchs who had no better instrument and excuse than faith to go on with their rules, aligned with a group of clergymen who were abusing the name of the faith. Naiini asserted that he began writing "A Warning..." as a religious duty to reveal that claims of despotic rulers are in conflict with Islam (Ibid: 535). His essay is a statement in rejecting despotism and emphasizing on the concept of religion of freedom, he maintained that with the victory of constitutional revolution the age of political despotism has ended and now religious branch of despotism is more dangerous than its political one and it is the main factor of the nation's decadence. Naiini believed that people's ignorance is a major contribution in their acquiesce to all sorts of despotism and he put criticism of this branch of despotism at the center of his interpretation of the religion of freedom; he defined religious despotism as willful claims of some of clerics which has been uttered in the name of faith and because of people's ignorance and unawareness they have been led to believe that these claims are the requirements of their faith and they should be obeyed (Turcoman, 1983, pp. 173-174).

Curing the disease of religious despotism would be difficult due to its penetration into the heart of people and because they believe it to be required by their faith while in fact it has no basis in Quran and it is even equal to renouncing monotheism (Taleghani, 1999, p. 25). The history of the emergence of religious despotism goes back to the caliphate of Muawiyah, the first Umayyad caliph who branded some venal people as companions of the prophet and tried to reject true religious authority by his fallacies. From then on religious and political despotism intermingled with each other and it led to current situation. Despotism lasted until the beginning of constitutional movement in Iran and with the establishment of a constitutional government all advocates of despotism from clerics to landlords and "Shah-worshippers" sallied to stifle freedom on the pretext of saving the faith and state (Ibid: 142). Naiini made allusions to the way to cure the disease as well, the only solution in his view was to explain the truth of despotism and constitutionalism to all classes of nation so that they understand that freedom of writing and speech and God-given liberties is for extricating themselves from the domination of unlawful rulers and to endeavor for their country's development and independence with their eyes and ears open (Ibid: 143). Eradication of the roots of despotic monarchy is the first step in the road to give people back their liberties and it won't be possible except by a comprehensive law in which duties of all classes of nation has been determined and public finances has been placed under the supervision of the elected members of parliament and of course no official should be able to disobey that law (Ibid: 152).

Then, Naiini tends to three questions that advocates and opponents of constitutionalism had differing views on them: first, the nature of tyranny and constitutionalism, second, constitution and national consultative assembly and third, explaining the meaning of freedom and equality. Naiini's basic arguments in explaining the first question is the repetition of fundamental principles of political thought, forming the government follows two major ends; regulation of individual's relations in a country and protection of the borders of that country. The criteria in distinguishing between various forms of government is securing and observing public interests. In a despotic monarchy, country is regarded as Shah's private property and people are his bonded servants (Ibid: 158) while in a constitutional monarchy state and political authority are fiduciaries given to shah's care and he should run them constitutionally and with regard to public interests, in this kind of monarchy incumbents of public offices are trustees of people and they should perform their duties in accordance with that trust and be accountable before the people (Ibid: 170). The political authority of an infallible Imam is like that of a constitutional monarch as well and in fact the most perfect form of constitutional monarchy is the one which is based on the infallibility of the ruler and that is among the principles of Shia faith; of course, Naiini's discussion of this kind of constitutional monarchy is extremely succinct because in the age of absence it could not be availed. In the age of absence and within the extent of human ability, one should try to create a monarchy which could be a shadow of the first kind of constitutional monarchies (Ibid: 212) and in which two fundamental pillars of constitution and the establishment of national consultative assembly has been observed. Constitution is a document in which public interests has been expressed and the extent of the interventions of the incumbents of public offices in the trust which has been given to their care has been determined, violation of this extent is malversation and it will cause dismissal of the offending incumbent and the exercise of due punishments in law (214). The second pillar of constitutional government is an assembly consisted of wise and benevolent people, they should be aware of international law and political requirements of the time and they should oversee the performances of the incumbents of public offices. Shutdown of each of these two pillars of constitutional monarchy will transform it into a despotic one. The end of constitutionalism is to secure and observe public interests and that will not be possible except by popular participation and by the supervision of people's representatives on the actions of Shah (Ibid: 216). In a reference to the history of early Islam, Naiini claimed that 
these principles were being observed on that time and it was thanks to them that the message of Islam was propagated so quickly. But when Muawiyah replaced Islamic constitutional government by tyranny, two branches of despotism joined together and they became two major factors in decadence of the Islamic world (Ibid: 217). The writer went on that our auspicious age will see the end of Muslim's decadence and it will witness their battle with two branches of despotism and the realization of freedom, it is for the same crack in the pillar of their tyranny, that custodians of despotism are trying to introduce freedom and equality which are the pillars of constitutionalism as things in conflict with Islam while they are both most incontrovertibly Islamic principles (Ibid: 219).

Here we should return to a point mentioned above that "A Warning..." is a political essay in the confines of Shia theory of unjust government according to which any government in which an infallible Imam is not at the top could not be seen as a legitimate government. As a Shia cleric, Naiini although declares the government of a just ruler to be rationally acceptable but it is certainly not religiously legitimate. All governments in the age of absence, whether by a just Shah or a tyrant one, are unjust governments however in any government two rights should be considered: the first one is a divine right and it means that all political authorities belong to God and he confers them to his chosen messengers so that they run them by observing public interests of the nation and the second right belongs to people who should be ruled. According to Shia theories observing these two rights is only possible in a government by an infallible Imam at the top but one should not draw the conclusion that there is no difference between various kinds of illegitimate governments. While it is true that political authority in every government by a ruler other than an infallible Imam is usurped and that government can't be counted as a legitimate one but there is a difference between constitutionally legitimate and constitutionally illegitimate governments and that is while both are unjust governments before Sharia but a government by a just ruler could still be accepted as a constitutionally legitimate one; note that in every religiously illegitimate government whether by a just ruler or a tyrant one, political authority which belongs to infallible Imams is usurped but in a government by a tyrant ruler the second right which belongs to people is also usurped because of the injustices it does to them while in government by a just ruler the right of people is observed thus it could be accepted as a constitutionally legitimate one. The main point in Naiini's arguments in justifying the legitimacy of constitutional government is that a government which usurps one right is better than one which usurps two rights, it is a rational matter-of-fact and the rules of Sharia can't be in conflict with what is necessitated by reason (Ibid: 219-220).

Naiini's defense of the legitimacy of constitutional government was extremely firm in terms of its logical arguments and consistent set of concepts; unlike Sheik Fazl-Allah who was disregarding the concepts was applying and the consistency between them, Naiini was never saying anything irrelevant and he even believed that the reason Sheik's statements are misleading in most cases is that the concepts he is applying in his writings are not crystal-clear and he always use them in place of each other. Rejection of doubts Sheik Fazl-Allah and his followers were spreading about the legitimacy of constitutional government has a special place in Naiini defense of constitutionalism; after explaining theoretical foundation of his defense of constitutional government and emphasizing that the concepts of constitutionalism should be interpreted in conjunction with the spirit of religion specially two blessed principle of freedom and equality, Naiini tends to fallacies of opponents of constitutionalism and reveals their corrupt sides in detail.

Since it seemed that among the concept that had been appeared with the beginning of Iran's constitutional movement, non was more in conflict with principles of Islam than the concept of freedom, Naiini discussed it in detail in his "A Warning to ..." Earlier, Mullah Ali Kani, one of the clerics of Nasir-al-Din Shah's period had referred to the concept as the "obscene word of Freedom", Sheik Fazl-Allah had introduced it as a concept contrary to worshipping God and meaning emancipation from his servitude as well. The point is particularly significant in this regard that with the victory of constitutional revolution intellectual debates transformed from the realm of disputations among enlightened thinkers into the realm of the one among religious advocates and opponents of constitutionalism; thus in the absence of secular intellectuals, advocacy or opposition to constitutionalism was more a contention between two differing understandings about religious learning than a one about a political order. Oppositions of Nouri and his followers to constitutionalism and Naiini's defense of it should be understood having in mind the same differing view about religious learning. With his accurate realization of the distinction between modern and traditional thought, his modern interpretation of the basics of traditional knowledge and with his having in mind the requirements of the modern Era, Naiini offered a thoroughly different understanding of religious learning and he defended constitutionalism with reliance on the same understanding. Pointing to decadence and ruinous situation of Muslims which is resulted from the alliance between two branches of despotism, religious and political, Naiini recognized national consciousness as the most 
fundamental factor in historical development and accused the advocates of religious despotism of collaboration with cruel rulers and abusing Quran and tradition to prevent the awakening of people (Ibid: 239-44). One of Sheik Fazl-Allah's fallacies which Naiini points to about the concept of freedom is the word's legal meaning in conflict with the concept of slavery in traditional system of knowledge. In Sheik's opinion freedom was opposed to God's servitude and Naiini brands this assertion as the masterpiece of Sheik in sophistry; freedom is a concept in conflict with people's captivity in tyrant political regimes. The truth of despotic monarchies is to captivate people to their willful dominations; it means that the nature of tyranny is to usurp the free wills of people while in un-despotic rules the principle is to free people from captivity (Ibid: 248-255) and the truth of constitutional movement is to turn cruel monarchy into a free government, this freedom means emancipation from political captivity not from the rules of Sharia and requirements of faith. In "A Warning" Naiini applied freedom in its political meaning and as a fundamental concept in explaining tyranny and constitutionalism and said that constitutionalism in not a new faith so that it could be in conflict with Islam. Believing in freedom is a common aspect in all religions and it is the political form of relations between individuals in a human community; in addition to being a principle of Islam, freedom is a rational matter-of-fact which has been emphasized by religion as well as those who renounce religion (Ibid: 284).

The second principle in question is equality which is also derived from the rules of Politics in Islam and Naiini regards it the basis and foundation of justice and spirit of all laws. In defining the meaning of equality he asserted that all laws of Sharia have been presented in a general way and they shall be equally executed in individual cases. In Naiini's opinion equality is a legal matter and it is obvious that no legal system can exist without a sense of equality, it means equal treatment with those who are equal and unequal treatment with those who are not and the same sense of equality is running in Islamic laws as well; in fact such a concepts is among the most noble laws of Islam, all those who are subjects of the laws of Sharia are equal before it and no discrimination will be accepted among them as all the laws special to Muslims and non-Muslims shall be remained effective in their own place (Ibid: 294). That equality which has been expressed in the constitution is not about canonical matters but it observes on secular matters and enacted laws. Enactment of laws was among the most severe objections of opponents of constitutionalism, with their straitlaced interpretation of Quran and tradition, Nouri and his followers believed the same two sources to be the sole law in Islam and they regarded any sort of secular and state enacted laws as a rival for Sharia. Nouri not only believed that these laws are innovation but also regarded their being obligatory as a second innovation and the punishment sentences for breaching them to be the third one. In reaction to his statements, Naiini asserted that enactment of state laws in parliament is not legislation in its canonical meaning (canonization) thus it couldn't be innovation; legislation would be innovation if and when it is presented as divine laws and rules of Sharia while regulating state affairs has nothing to do with Sharia that kind of legislations discussed between Shia jurists but it is human legislation on regulating secular matters and promoting public interests. Such laws being obligatory is not innovation as well since when it is supposed that such laws are the result of deliberations between wise elected representatives of the nation, its observance should be obligatory for all. At the end of his arguments, Naiini added that of course, the intention of all these nonsenses they (opponents of constitutionalism) are weaving together is to prevent destruction of the foundations of their cruel government (ibid: 297).

Among essays written to justify constitutional thought in a religious context, there is none to use all the facilities of the Shia jurisprudence's terminology better than that of Naiini. Public is not Naiini's audience but clerics like Nouri are; Naiini refers to sophistries of those like Nouri and his followers throughout his essay and most strongly reveal their corrupt sides. He believed that a huge step has been taken to establish a national government in Iran following the establishment of the constitutional government and the institution of the national assembly and he wrote his "A Warning" in an effort to offer a canonical justification in the confines of Shia theory of unjust government for constitutionalism; viewed in that regard, Naiini's essay is not only a significant one in terms of constitutionalism and the rule of law theory but also the first step in an unprecedented development toward a modern Shia political thought.

\section{References}

Abadian, H. (1988). Religious Thought and Tobacco Movement in Iran. Tehran: the institute for the study of contemporary history of Iran.

Abadian, H. (1995). Theoretical Foundations of constitutional and theocratic government. Tehran: Ney publication.

Abadian, H. (2002). The Crisis of Legitimacy in Iran. Tehran: the institute for the study of contemporary history of Iran. 
Adamiat, F. (1972). The Idea of Progress and the Rule of Law. Tehran: Khwarazmi publication.

Adamiat, F. (1974). Historical Essays. Tehran: Shabgir publication.

Adamiat, F. (1976a). The Idea of social Democracy in Constitutional Movement. Tehran: Khwarazmi publication.

Adamiat, F. (1976b). The Ideology of Constitutional Movement of Iran. Tehran: Payam Publication.

Adamiat, F. (1982). Disorder in Historical Thought. Tehran: Jahan-e-Andishe Supplement.

Afary, J. (2000). Constitutional Revolution of Iran (Trans. by Rezai Reza). Tehran: Bisotun Publication.

Ajudani, M.-A. (1997). Iranian Mashrooteh: backgrounds of the theory of Velayat-e-Faqih. London: Fasl-e-Ketab Publication.

Algar, H. (1980). The Role of Progressive Clerics in Constitutional Revolution. Tehran: Qos publication.

Amir Arjoman, S. (1984). The Shadow of God and the Hidden Imam. Chicago: University of Chicago Press. http://dx.doi.org/10.7208/chicago/9780226924809.001.0001

Amir Arjoman, S. (1988). The Turban for the Crown: The Islamic Revolution in Iran. Oxford: University Press.

Amir Arjoman, S. Constitutional Politics in the Middle East: With Special Reference to Turkey, Iraq, Iran and Afghanistan.

Ansari, M. (1998). Sheik Fazl-al_Allah Nouri and Constitutionalism: Encounter between Two Thoughts. Tehran: Amir Kabir.

Asadabadi, S. J. (1978). Seyed Jamal's Letters (Ed. by Jamali Abo-al-Hassan). Tehran: Islamic publications.

Asadabadi, S. J. (1982). Jamaliye Essays (Ed. by Jamali Abo-al-Hassan). Tehran: Amir Kabir.

Ayatolahi, M. T. (1984). Velayat-e-Faqih: Intellectual Infrastructure of Constitutional and Theocratic government: A Journey into the Thought and Struggles of Seyed Abd-al-Hussein Lari. Tehran: Amir Kabir.

Bayat, M. Iran's First Revolution: Shi'ism and Constitutional Revolution of 1905-1906.

Brown, E. (1998). Constitutional Revolution of Iran (Trans. by Qazvini Mehri). Tehran: Kavir Publication.

Haeri, A.-al-H. (1982). Shi'ism and Constitutionalism: Constitutionalism in Iran and the Role of Shia Ulama in Iraq. Tehran: Amir Kabir.

Hashemi, S. T. (2006). Mirza-e-Naiini and the Political System of Mashruteh. Tehran: Mehrnamag.

Iran National Library. (2000). Political Treatises of the Qajar Period (Ed. by Zargari Nejad). Tehran.

Khorasani, M. K. (2006). Siyasat-Nameh (Ed. by Kadivar Mohsen). Tehran: Kavir publication.

Koselleck, R. (1988). Critique and Crisis: Enlightenment and the Pathogenesis of Modern Society. Cambridge, Mass: MIT Press.

Koselleck, R. (2002). The Practice of Conceptual History: Timing History, Spacing Concepts. Trans. into English by Presner, Todd Samuel, Stanford: University Press.

Lambton, A. (1981). State and Government in Medieval Islam: an Introduction to the Study of Islamic Political Thought. Oxford: University Press.

Naiini, S. M. H. (2000). Tanbih-al-Umah and Tanzih-al-Melah (A Warning to the Faith Community and Purification of the Nation) (Ed. by Taleqani Seyed Mahmoud). Tehran: Enteshar Co.

Nateq, H., \& Adamiat, F. (1977). Economic and Socio-Political Thoughts in Unpublished Works of Qajar Period. Tehran: Agah publication.

Nouri, S. F.-al-A. (1983). Petitions of Sheik Fazl-Allah. (Ed. by Rezvani Homa). Tehran: Tarikh publication.

Nouri, S. F.-al-A. (1983). Treatise, Announcements and Writings of Sheik Fazl-Allah Nouri (Ed. by Torkaman, Mohammad). Tehran: Rasa institute of Cultural Services.

Rajaee, F. Islamism and Modernism: Changing Discourse in Iran.

Rosenthal, E. (1962). Political Thought in Medieval Islam. Cambridge: University Press.

Tabatabai, S. J. (2008). The Theory of the Rule of Law in Iran. Tehran: Sotudeh.

Tabrizi, M. F. A. (1993). Memoires and Letters of Mirza Fazl Ali Tabrizi (Ed. by Mirza Saleh \& Gholam Hussein). Tehran: Tarh-e-No. 
Tehran University Publications. (2005). Review of Intellectual and Social Foundations of Constitutionalism: Commemoration of Ayatollah Mohammad Kazem Khorasani.

Tierny, B. (1982). Religion, Law and the Growth of Constitutional Thought: 1150-1950. Cambridge: University Press. http://dx.doi.org/10.1017/CBO9780511558627

Vosuqi, M. B. (2004). Ayatollah Seyed Abd-al-Hussein Lari and the Constitutional Movement. Tehran: Archive of Islamic Revolution.

\section{Notes}

Note 1. "Lesser Tyranny" is a one-year period in Iran's political history from June 1908 (date of the first Majlis's shot down by Mohammad-Ali Shah) until June 1909 (Tehran's occupation by forces loyal to constitutionalism and the overthrow of Mohammad-Ali Shah).

Note 2. Mohammad ibn Hasan al-Mahdi who is believed by Twelver Shi'a Muslims to be the Mahdi, an ultimate savior of humankind and the final Imam of the Twelve Imams who will emerge in order to fulfill their mission of bringing peace and justice to the world. (https://en.wikipedia.org/wiki/Muhammad_al-Mahdi).

Note 3. Talibof, Abdo-al-Rahim, "The Book of Ahmad", Ed. Momeni, Baqer, Tehran: Pocket Books, 1967, p: 132.

\section{Copyrights}

Copyright for this article is retained by the author(s), with first publication rights granted to the journal.

This is an open-access article distributed under the terms and conditions of the Creative Commons Attribution license (http://creativecommons.org/licenses/by/4.0/). 